\title{
Mewujudkan Kedaulatan Pangan Melalui Kegiatan Perluasan Sawah
}

\author{
Djaimi Bakce (i) \\ Jurusan Agribisnis, Fakultas Pertanian, Universitas Riau \\ *djaimibakce@yahoo.com
}

\begin{abstract}
Abstrak. Dalam rangka mewujudkan kedaulatan pangan, salah satu upaya yang dapat dilakukan adalah dengan menerapkan kebijakan ekstensifikasi melalui perluasan sawah baru. Tulisan ini bertujuan untuk menginformasikan tentang kendala yang dihadapi dan solusi yang diusulkan dalam menentukan lokasi yang layak dari aspek calon lokasi dan aspek calon petani untuk ilmu pengetahuan lebih lanjut dan pencetakan sawah. Survei investigasi dan desain lapangan cetak sawah dilakukan di 7 kabupaten di Provinsi Riau. Temuan utama yang diperoleh adalah: Pertama, sebagian besar calon lokasi yang tidak layak karena termasuk dalam kawasan hutan, sehingga kebijakan khusus perlu diterapkan mengingat beras merupakan kebutuhan dasar bagi penduduk Indonesia. Kedua, terdapat calon lahan yang memenuhi syarat tergantung pada aspek kesesuaian lahan dan irigasi sehingga perlakuan teknis khusus. Ketiga, terdapat calon petani yang belum pernah berusahatani padi, sehingga untuk berhasil dalam Program Ekstensi Beras, penyuluhan dan pendampingan diperlukan bagi petani dari aspek teknis produksi pertanian dan manajemen, serta manajemen kelompok tani. Keempat, dalam perluasan sawah baru biaya yang telah ditetapkan pada Rp. 16 juta/ ha, sedangkan di lapangan banyak kesulitan yang ditemukan, tergantung pada topografi, lokasi dan kebutuhan infrastruktur yang sedang dibangun. Oleh karena itu ada lokasi yang membutuhkan lebih banyak anggaran karena harus membangun sejumlah infrastruktur seperti pintu permanen atau tanggul sehingga sawah aman dari bahaya banjir atau pasang.
\end{abstract}

Kata Kunci: kedaulatan pangan, ekspansi lahan padi, survei investigasi, desain

\section{PENDAHULUAN}

Salah satu agenda strategis pemerintah kabinet kerja adalah mewujudkan kedaulatan pangan di Indonesia. Menurut Undang-undang Nomor 18 Tahun 2012 tentang Pangan, kedaulatan pangan adalah hak negara dan bangsa yang secara mandiri menentukan kebijakan Pangan yang menjamin hak atas Pangan bagi rakyat dan yang memberikan hak bagi masyarakat untuk menentukan sistem Pangan yang sesuai dengan potensi sumber daya lokal.

Secara lebih detail, Direktorat Perluasan dan Perlindungan Lahan Direktorat Jenderal Prasarana dan Sarana Pertanian Kementerian Pertanian Republik Indonesia (2016) menyatakan bahwa kedaulatan pangan adalah dalam bentuk kemampuan bangsa dalam hal: (1) mencukupi kebutuhan pangan dari produksi dalam negeri, (2) mengatur kebijakan pangan secara mandiri, serta (3) melindungi dan mensejahterakan petani sebagai pelaku utama usaha pertanian pangan. Dengan kata lain, kedaulatan pangan harus dimulai dari swasembada pangan yang secara bertahap diikuti dengan peningkatan nilai tambah usaha pertanian secara luas untuk meningkatkan kesejahteraan petani.

Upaya pencapaian swasembada dapat dilakukan dengan dua pendekatan, yaitu dengan peningkatan IP, provitas sawah-sawah eksisting dan penambahan baku lahan sawah. Peningkatan produksi padi melalui perluasan sawah masih dimungkinkan karena potensi lahan yang sesuai untuk perluasan sawah cukup luas. Sebelum melaksanakan kegiatan perluasan sawah, terlebih dahulu diperlukan perencanaan yang baik agar pelaksanaan kegiatan perluasan juga berjalan dengan baik. Rangkaian kegiatan perencanaan perluasan sawah dimulai dari kompilasi usulan, identifikasi Calon Petani dan Calon Lokasi (CP/CL) dan kemudian disempurnakan melalui kegiatan survei dan investigasi calon lokasi serta pembuatan disain terhadap lokasi yang layak untuk dijadikan sawah baru.

Tujuan kegiatan SI-CPCL perluasan sawah adalah menyiapkan dokumen perencanaan perluasan sawah baru berupa data hasil survei dan investigasi pada calon lokasi perluasan sawah yang menyatakan layak tidaknya suatu lokasi untuk sawah. Sasaran kegiatan SI-CPCL perluasan sawah yaitu lokasi yang 
mempunyai potensi lahan untuk dikembangkan menjadi sawah baru dan sesuai berdasarkan RTRW Provinsi atau Kabupaten/Kota.

Sementara itu, kegiatan pemetaan disain cetak sawah bertujuan untuk: (1) Mengukur elevasi untuk membuat peta topografi, (2) Mengukur kondisi vegetasi untuk menganalisis vegetasi, (3) Mengamati potensi pengairan dan menganalisis kecukupan air, (4) Mendisain petak sawah, (5) Mendisain saluran irigasi dan drainase, (6) Mendisain jalan usaha tani, dan (7) Menyusun RAB cetak sawah. Sasaran dari pemetaan design cetak sawah adalah sebagai acuan/pedoman dalam kegiatan pencetakan sawah baru.

Dalam pelaksanaan kegiatan SI-CPCL dan Pemetaan Disain Cetak Sawah ditemukan sejumlah kendala yang perlu dirumuskan solusinya sehingga program/kegiatan yang dicanangkan dapat dilaksanakan dengan baik, mencapai tujuan akhir yang diharapkan. Kendala yang dihadapi meliputi upaya untuk memenuhi persyaratan kelayakan calon lokasi dan calon petani, dan kendala dalam implementasi pencetakan sawah.

Berdasarkan pemikiran di atas, makalah ini ditulis dengan tujuan untuk menginformasikan tentang kendala yang dihadapi dan solusi yang diusulkan dalam menentukan lokasi yang layak dari aspek calon lokasi maupun aspek calon petani untuk selanjutnya dilakukan disains dan pencetakan sawah. Standar penentuan kelayakan calon lokasi dan calon petani mengacu pada Pedoman Teknis Survei Dan Investigasi Calon Petani-Calon Lokasi Dan Pemetaan Disain Perluasan Sawah Tahun 2016 yang diterbitkan oleh Direktorat Perluasan dan Perlindungan Lahan Direktorat Jenderal Prasarana dan Sarana Pertanian Kementerian Pertanian Republik Indonesia.

\section{METODE}

\section{Lokasi dan Waktu}

Survei dan investigasi Calon Petani dan Calon Lokasi (SI-CPCL) dan Pemetaan Disain Cetak Sawah ini dilakukan pada 7 (tujuh) kabupaten di Provinsi Riau, yaitu Kabupaten Kepulauan Meranti, Kabupaten Bengkalis, Kabupaten Rokan Hilir, Kabupaten Rokan Hulu, Kabupaten Kampar, Kabupaten Indragiri Hulu dan Kabupaten Siak. Waktu penyelesaian kegiatan SI-CPCL dan Disain selama 6 (enam) bulan JuliDesember 2017.

\section{Jenis, Sumber Data, dan Variabel yang Diukur}

Jenis data yang dikumpulkan dalam kegiatan ini terdiri dari data primer dan sekunder. Data yang dibutuhkan, sumber data dan variabel yang diukur serta teknik pengumpulannya dalam kegiatan SI CPCL dan pemetaan disain cetak sawah di Provinsi Riau.

Tahap Pelaksanaan Survei dan Investigasi dan Pemetaan Disain

(a) Persiapan

Persiapan yang dilakukan dalam survei dan investigasi adalah:

(1) Inventarisasi data sekunder serta peta-peta yang dibutuhkan;

(2) Pengadaan dan perbanyakan instrumen pengumpulan data di lapangan;

(3) Pembelian alat dan bahan yang dibutuhkan dalam pengumpulan data;

(4) Diskusi tenaga ahli untuk penyempurnaan tahap persiapan.

(b) Pelaksanaan survei dan investigasi, dan pemetaan disain

Kegiatan yang dilakukan dalam pelaksanaan survei dan investigasi sebagai berikut:

(1) Penyiapan data dan bahan pendukung.

Sebelum dilaksanakan survei lapangan oleh pelaksana, dilakukan penyiapan peta-peta dasar, bahan dan peralatan, serta kuesioner survei/daftar pertanyaan untuk investigasi lokasi perluasan sawah.

(2) Pelaksanaan survei pemetaan situasi dan investigasi kawasan.

Survei ini ditujukan untuk memetakan lokasi yang direncanakan untuk perluasan sawah dan dibuat peta polygon lahan. Survei dapat dilakukan secara terestrial atau secara aerial. Lokasi dipetakan pada peta situasi skala 1:10.000. Peta situasi calon lokasi memuat data sebagai berikut:

a) Poligon lahan yang disurvei dan dilengkapi dengan titik koordinat.

b) Batas pemilikan lahan setiap petani sebelum direncanakan menjadi petak-petak sawah.

c) Peruntukan lahan saat ini, misalnya persawahan, kawasan hutan, perkebunan dan sebagainya.

d) Batas administrasi pemerintahan, misalnya batas Kampung, Desa, Kecamatan, Kabupaten, dan sebagainya. 
e) Batas tata guna lahan/vegetasi lahan seperti hutan alam/ primer, hutan sekunder, semak belukar, tegalan dan alang-alang.

f) Seluruh alur sungai, tata letak jaringan pengairan, bangunan irigasi, drainase dan bangunan lainnya.

g) Tata letak jaringan jalan yang ada terutama jalan negara, jalan provinsi, jalan kabupaten, jalan kecamatan, jalan desa, dan jalan setapak ke lokasi perluasan sawah.

Pada kegiatan ini juga dilakukan investigasi dan koordinasi dengan instansi terkait yaitu:

a) Dinas Lingkungan Hidup dan Kehutanan Provinsi;

b) Badan Pertanahan Nasional (BPN) Provinsi;

c) Badan Perencanaan Pembangunan Daerah (Bappeda) Provinsi.

Investigasi dan koordinasi ini dimaksudkan untuk memastikan bahwa:

a) Lokasi tidak masuk kawasan hutan, kawasan moratorium pemanfaatan lahan gambut, kawasan Penetapan Peta Indikatif Penundaan Pemberian Izin Baru (PIPPIB) Pemanfaatan hutan, dan kawasan yang sudah dibebani hak dan izin lainnya. (Koordinasi dengan Dinas Lingkungan Hidup dan Kehutanan dan BPN;

b) Lokasi tidak masuk kawasan sawah eksisting. Pengecekannya dilakukan dengan menggunakan peta lahan sawah kesepakatan pemerintah dan citra terbaru (dapat dari google earth). Lokasilokasi yang berdasarkan peta lahan sawah kesepakatan pemerintah masuk dalam kawasan sawah eksisting namun secara faktual bukan lahan sawah, apabila tetap dimasukkan dalam rencana perluasan sawah harus mendapatkan surat keterangan yang menyatakan bahwa lokasi bukan merupakan sawah eksisting dan lahan bekas sawah. Surat keterangan dapat diminta kepada kepala desa dan camat (Koordinasi dengan BPN);

c) Lahan tidak memiliki sengketa pemilikan atau penguasaan (Koordinasi dengan BPN);

d) Tata ruang sesuai untuk perluasan sawah (Koordinasi dengan Bappeda);

e) Jenis status kepemilikan lahan (tanah milik, tanah adat atau tanah negara) dan tidak terdapat kendala pengembangan sebagai konsekuensi dari status kepemilikan lahan (Koordinasi dengan BPN dan Bappeda).

Hasil koordinasi dengan instansi-instansi tersebut dituangkan dalam Berita Acara atau notulensi dengan menyertakan penjelasan mengenai kondisi setiap calon lokasi.

(3) Pelaksanaan survei dan investigasi sosial ekonomi.

Survei ini dimaksudkan untuk mendapatkan data dan informasi yang berkaitan dengan kondisi sosial dan ekonomi masyarakat pada calon lokasi kegiatan perluasan sawah. Responden pada kegiatan ini meliputi masyarakat calon penerima kegiatan. Survei dan investigasi ini menjajaki beberapa kondisi berikut:

a) Identitas Calon Penerima kegiatan perluasan sawah

b) Keadaan petani, ada tidaknya petani, jumlah petani dan domisili petani serta kesediaan petani untuk mengubah fungsi lahannya menjadi sawah, daftar nama petani, luas lahan serta jenis vegetasinya,

c) Status ekonomi calon penerima kegiatan

d) Kesiapan calon petani penerima dalam mengusahakan sawah baru dan kesediaannya untuk tidak mengalih fungsikan lahan sawah baru

e) Kondisi sosial dan ekonomi yang berpotensi menjadi kendala kesuksesan program perluasan sawah.

f) Respon masyarakat sekitar non penerima terhadap rencana kegiatan perluasan sawah.

g) Analisa ekonomi terhadap rencana perluasan sawah.

h) Rekomendasi aspek sosial ekonomi terkait kondisi calon petani dan calon lokasi untuk kesuksesan program.

i) Peruntukan lahan tidak tumpang tindih dengan program dan proyek lain.

(4) Pelaksanaan survei evaluasi kesesuaian lahan untuk sawah.

a) Evaluasi kesesuaian Lahan dapat dilakukan dengan metode Uji Cepat (Quick Assasement) oleh pihak yang kompeten dan berpengalaman dalam bidang pemetaan tanah dan evaluasi kesesuaian lahan. 
b) Jenis tanah berupa sifat fisik tanah yang meliputi tekstur, $\mathrm{pH}$, kadar bahan organik dan kategori vegetasi calon lokasi perluasan sawah.

c) Keadaan tanah yang sesuai untuk pertumbuhan tanaman padi.

d) Survei dan pemetaan harus dilakukan minimal pada skala pemetaan 1:25.000 dengan intensitas pengamatan tanah 1 (satu) observasi mewakili 15-30 ha lahan.

e) Pengamatan tanah melalui pemboran atau profil tanah yaitu:

- Untuk tanah mineral sampai kedalaman minimal 1,2 m, jika terdapat batuan kukuh dapat lebih dangkal.

- Untuk tanah gambut sampai kedalaman 1,5 m jika ketebalan gambut $<1 \mathrm{~m}$ atau sampai substratum (tanah mineral) jika ketebalan gambut $>1 \mathrm{~m}$.

- Metode evaluasi lahan mengacu pada Petunjuk Teknis Evaluasi Lahan untuk Komoditas Pertanian (BBSDLP, 2011) dengan modifikasi sesuai kondisi setempat. Kriteria yang disebutkan dibawah ini dengan asumsi bahwa penilaian terhadap 2 kualitas lahan dari kesuburan tanah, yaitu: retensi hara (KTK, KB dan C-organik, kecuali pHtanah) dan hara tersedia (N, P dan K) belum termasuk. Penilaian kedua kualitas lahan tersebut akan dilakukan dalam rekomendasi teknologi pengelolaan lahan khususnya perbaikan kesuburan tanah.

(5) Pelaksanaan survei potensi pengairan.

Survei dimaksudkan untuk menyajikan data sebagai berikut:

a) Informasi daerah tangkapan air (DTA) sumber air dan prediksi sebaran debit bulanan dan musimannya dalam siklus setahun

b) Informasi lokasi sumber air dan elevasi lokasi pengambilannya serta jarak dari lokasi

c) Informasi kondisi jaringan utama (primer dan sekunder) yang telah/ pernah diselesaikan.

d) Ketersediaan dan keadaan jaringan tersier di Daerah Irigasi.

e) Pengukuran debit pada setiap obyek sumber air baik mata air, atau aliran sungai.

f) Analisis kecukupan ketersediaan air untuk irigasi dan sawah yang dicetak untuk menjamin pertumbuhan padi beserta keterangan penggunaan lainnya saat ini

g) Peta situasi pada titik sumber pengambilan air

h) Mengetahui prasarana dan sarana yang dibutuhkan untuk pengairan. Prasarana dan sarana yang dimaksud seperti saluran, pintu air, box bagi, embung, pompa air, pipa dan lainnya.

(c) Penetapan Kriteria Kelayakan Calon Lokasi dan Calon Petani Perluasan Sawah

Kriteria lokasi yang dapat diusulkan adalah sebagai berikut:

(1) Status kepemilikan tanah jelas, misalnya: tanah milik atau tanah rakyat (marga) atau tanah negara yang diizinkan untuk digarap oleh petani.

(2) Batas pemilikan tanah jelas (tidak sengketa).

(3) Lokasi tidak pernah dijadikan sawah sebelumnya.

(4) Kemiringan lahan diutamakan $<8 \%$.

(5) Dalam satu hamparan minimal seluas $5 \mathrm{Ha}$ atau sesuai skala ekonomi untuk pembukaan lahan baru.

(6) Apabila jenis lahannya berupa lahan gambut, maka maksimal ketebalan gambut 1 meter dan kedalaman pirit minimal $60 \mathrm{~cm}$.

(7) Tanah sesuai untuk padi sawah dan tidak diarahkan untuk sawah tadah hujan.

(8) Dalam RTRW, calon lokasi masuk dalam kawasan budi daya pertanian atau pengembangan budidaya pertanian. Calon lokasi tidak boleh berada dalam kawasan hutan (baik HPK, HP, HPT, HL, HVCA), kawasan moratorium pengembangan gambut, kawasan HGU atau kawasan yang telah dibebani hak dan izin lainnya.

(9) Lahan tidak tergenang air selama 3 bulan berturut-turut.

(10) Petani ada dan berdomisili di desa calon lokasi atau berdekatan dengan calon lokasi serta berkomitmen untuk bersawah.

(11) Jika terdapat lahan pada calon lokasi yang pemiliknya tidak berdomisili di desa calon lokasi, maka mengikuti hal-hal sebagai berikut:

a) Bersedia mengikuti program perluasan sawah dan menunjuk penggarap untuk mengerjakan sawah yang akan dicetak, maka harus dinyatakan secara tertulis dalam surat kesepakatan antara pemilik lahan dengan penggarap. 
b) Jika pemilik tidak bisa dihubungi/tidak bersedia mengikuti program dan lahan tersebut tidak bisa dimasukkan dalam program.

(d) Pemetaan Disain Cetak Sawah

Kegiatan pemetaan disain cetak sawah meliputi:
a. Pengukuran elevasi untuk membuat peta topografi
b. Pengukuran kondisi vegetasi untuk menganalisis vegetasi
c. Pengamatan potensi pengairan dan menganalisis kecukupan air
d. Mendisain petak sawah
e. Mendisain saluran irigasi dan drainase
f. Mendisain jalan usaha tani
g. Pengusunan RAB cetak sawah.

\section{HASIL DAN PEMBAHASAN}

\section{Pemetaan Situasi dan Investigasi Kawasan}

Mengacu pada Pedoman Teknis Survei dan Investigasi Calon Petani-Calon Lokasi dan Pemetaan Disain Perluasan Sawah Tahun 2016 yang diterbitkan oleh Dirjen PSP Kementerian Pertanian Republik Indonesia. Pengukuran dan survei investigasi kawasan berdasakan kriteria lokasi, batas pemilikan tanah jelas (tidak sengketa), lokasi tidak pernah dijadikan sawah sebelumnya, Kemiringan lahan diutamakan $<8 \%$. Dalam satu hamparan minimal seluas $5 \mathrm{Ha}$ atau sesuai skala ekonomi untuk pembukaan lahan baru tidak berada pada lahan gambut dengan kedalaman > 1 meter. Diperoleh hasil pengukuran seluas 2.698,37 ha yang tersebar di Kabupaten Kampar, Indragiri Hulu, Rokan Hilir, dan Kabupaten Kepulauan Meranti.

Berdasarkan hasil survei pemetaan situasi dan investigasi kawasan serta tutupan lahan dapat dinyatakan bahwa:

(1) Terdapat perbedaan luas antara usulan dengan hasil pengukuran dan terdapat perbedaan lokasi antara usulan dan hasil pengukuran

(2) Tidak semua lokasi yang diusulkan dapat dilakukan pengukuran, berdasarkan hasil investigasi awal dilapangan terdapat lokasi yang diusulkan merupakan sawah eksisting dan lokasi yang telah dilakukan survei investigasi sebelumnya.

(3) Dari lokasi yang diusulkan, diukur dan dilakukan investigasi kawasan, sebahagian lokasi masuk dalam non-kawasan hutan dan kawasan hutan. Yang masuk kedalam kawasan hutan berupa Hutan Produksi Terbatas (HPT)

(4) Tutupan vegetasi pada seluruh lokasi yang diamati umumnya berupa tanah terbuka, lahan sawah eksisting, semak belukan, lahan perkebunan dan hutan sekunder.

(5) Berdasarkan kriteria kondisi vegetasi di wilayah Kabupaten Kampar yang meliputi 3 desa di tiga kecamatan dapat dikategorikan kedalam kelas Vegetasi Ringan (+63,0 \%), Vegetasi Sedang $(+20 \%)$ dnan kelas vegetasi Berat $(+17 \%)$.

(6) Berdasarkan kriteria kondisi vegetasi di wilayah Kabupaten Indragiri Hulu yang meliputi 4 desa di dua kecamatan dapat dikategorikan kedalam kelas Vegetasi Ringan $(+57,0 \%)$, Vegetasi Sedang $(+8 \%)$ dnan kelas vegetasi Berat $(+36 \%)$.

(7) Berdasarkan kriteria kondisi vegetasi di wilayah Kabupaten Kepulauan Meranti yang meliputi 13 desa dan tersebar di tujuh kecamatan dapat dikategorikan kedalam kelas Vegetasi Ringan $(+61,0 \%)$, Vegetasi Sedang (+ $24 \%)$ dnan kelas vegetasi Berat (+ 15\%).

\section{Kesesuaian Lahan}

Dalam menentukan potensi lahan untuk dijadikan sawah, Pusat Penelitian Tanah, (1983) menentukan sifatsifat sebagai berikut: (1) Kedalaman efektif tanah antara $25-75 \mathrm{~cm}$, (2) Tekstur lapisan atas lebih halus dari lempung halus, (3) Kandungan batu-batu di permukaan kurang dari 50\%, (4) $\mathrm{pH}$ tanah antara 3,0 - 8,0, (5) Kedalaman lapisan yang mengandung pirit 1,5\% lebih dalam dari $25 \mathrm{~cm}$, (6) Lereng < $5 \%$, (7) Ketinggian tempat $<1000 \mathrm{~m} \mathrm{dpl}$, (8) Kedalaman genangan kurang dari $75 \mathrm{~cm}$, (9) Kelas drainase tanah agak terhambat sampai terhambat, (10) Banjir < 4 bulan setahun, (11) Salinitas air < $4000 \mathrm{mmhos} / \mathrm{cm}$, dan (12) Untuk tanah gambut, kedalaman gambut $<150 \mathrm{~cm}$ dan tingkat dekomposisi gambut adalah saprik sampai hemik.

Selanjutnya Houser dan Sadikin (1956) dalam Fagi dan Las (1988) mengatakan bahwa padi yang ditanam di tanah yang telah mengalami pelapukan lanjut memberikan hasil rendah. Namun demikian, kenyataannya menunjukkan bahwa sistem sawah menyebabkan terjadinya modifikasi sifat fisik dan kimia 
tanah, dimana sistem sawah cenderung meningkatkan kesuburan tanah. Produktifitas lahan sawah lebih tinggi dari lahan gogo. Hal ini karena dengan sistem sawah reaksi tanah mendekati netral, ketersedian P, kalium, besi, mangan, dan silikat meningkat, suasana reduksi menyebabkan pirit (FeS2) tidak meracun, penyawahan (penggenangan) juga menekan pertumbuhan gulma, dan lain-lain.

Namun permasalahan yang sering terjadi jika budidaya sawah dilakukan pada lahan-lahan marginal. Budidaya sawah di lahan tersebut, untuk mendapatkan tingkat produksi yang baik dan menguntungkan secara ekonomis, maka penggunaan paket teknologi menjadi suatu keharusan. Tanpa paket teknologi yang tepat, budidaya tersebut akan berisiko gagal, dan hal ini tidak boleh terjadi karena akan merugikan petani secara ekonomi dan sosial (Utama, 2015). Oleh karena itu pengembangan lahan sawah pada lokasi-lokasi yang masih memberi peluang besar untuk ditingkatkan luasan areal baku dan areal panennya, perlu dikaji sifat dan ciri tanah serta kelas kesesuaian lahannya.

Evaluasi kesesuaian lahan yang dilakukan adalah untuk memilih bidang lahan yang sesuai untuk komoditas padi sawah. Penanaman padi (Oryza sativa) pada lahan sawah memerlukan lahan yang datar (kemiringan $<8 \%$ ) dan tanah harus berdrainase buruk sampai tidak sempurna dengan tekstur lapisan atas lebih halus dari pasir berlempung. Tekstur tanah yang kasar tidak hanya tidak subur, tetapi juga dapat menyebabkan kehilangan air melalui perkolasi. Akan tetapi pada areal yang rendah dan dimana tekstur lapisan bawah lebih berat dari lempung berpasir halus, tanah ini akan sesuai untuk padi sawah. Tanah ini paling sedikit membutuhkan empat bulan secara berturut-turut dengan curah hujan lebih dari $200 \mathrm{~mm}$. Banjir yang berkepanjangan merupakan pembatas untuk tanaman ini.

Metode evaluasi lahan untuk sawah baru mengacu pada Petunjuk Teknis Evaluasi Lahan untuk Komoditas Pertanian (BBSDLP, 2011) dengan modifikasi sesuai kondisi setempat. Kriteria yang disebutkan dibawah ini dengan asumsi bahwa penilaian terhadap 2 kualitas lahan dari kesuburan tanah, yaitu: retensi hara (KTK, KB dan C-organik, kecuali pH-tanah) dan hara tersedia (N, P dan K) belum termasuk. Penilaian kedua kualitas lahan tersebut akan dilakukan dalam rekomendasi teknologi pengelolaan lahan khususnya perbaikan kesuburan tanah. Dalam Buku Pedoman Teknis Survei dan Investigasi Calon Petani-Calon Lokasi dan Pemetaan Disain Perluasan Sawah Tahun 2016, secara rinci syarat-syarat tumbuh minimum tanaman padi sawah yang jadi parameter dalam menilai kesesuaian lahan adalah sebagai berikut: (1) Temperatur $>21 \mathrm{oC}$ atau setara dengan <1000 m dpl untuk batas Kelas, (2) Kesesuaian Lahan (KKL) S3 (Sesuai Marjinal), (3) Sumber Air dari Curah hujan, air permukaan (sungai, rawa) atau air tanah, (4) Sawah Irigasi: ada air irigasi, (5) Sawah Tadah Hujan: Curah hujan >1000 mm/th; Bulan Basah (curah hujan 200 $\mathrm{mm} / \mathrm{bulan}$ ) minimal 3 bulan, (6) Sawah Pasang Surut: Tipe luapan A dan B dengan salinitas air <4 dS/m; Tipe C dan D dari curah hujan $>1000 \mathrm{~mm} / \mathrm{th}$. Bulan Basah (curah hujan $200 \mathrm{~mm} / \mathrm{bulan}$ ) minimal 3 bulan, (7) Sawah Lebak: Curah hujan/bulan kering (curah hujan $<100 \mathrm{~mm} / \mathrm{bulan}$ ) 2-8 bulan, (8) Tekstur tanah lebih halus dari pasir berlempung; dan bahan kasar (kerikil, batu) $<35 \%$, (9) Kedalaman tanah $>25 \mathrm{~cm}$, (10) Kedalaman pirit $>50 \mathrm{~cm}$ dari permukaan tanah mineral, (11) Ketebalan gambut $<1 \mathrm{~m}$ dengan tingkat kematangan hemik dan saprik, (12) Kemasaman tanah $(\mathrm{pH})>3,5$, (13) Salinitas tanah maksimal $2 \mathrm{dS} / \mathrm{m}$ (mmhos/cm), (14) Bahaya banjir/genangan tidak lebih dari 14 hari dengan ketinggian $<75 \mathrm{~cm}$, (15) Lereng diutamakan $<8 \%$, dan (16) Batuan di permukaan tanah $<40 \%$.

Penilaian kelayakan calon lahan berdasarkan kesesuaiannya mempertim-bangkan sifat-sifat lahan yang mempengaruhi pertumbuhan dan produksi tanaman serta pemanfaatan/ pengelolaan lahan. Kualitas/karakteristik lahan yang menjadi kriteria digolongkan kedalaman iklim, sifat tanah, dan terrain. Data iklim merupakan data sekunder yang diperoleh dari BMKG, sedangkan data karakteristik tanah dan terrain dikumpulkan melalui survei lapangan.

Berdasarkan hasil survei dan evaluasi kesesuaian lahan serta penilaian kelayakan dari aspek kesesuaian lahannya dapat dinyatakan bahwa:

(1) Semua calon lahan (CL) perluasan sawah tahun 2017 di Kabupaten Kampar (77,17 ha) dan Indragiri Hulu (22,99 ha) memiliki kelas kesesuaian lahan S2, sehingga layak untuk didisain guna perluasan sawah.

(2) Calon lahan perluasan sawah tahun 2017 di Kabupaten Rokan Hilir (1.969,60 ha) memiliki kelas kesesuaian lahan S1-S3 (1.354,27 ha) dan N2 (615,33 ha), sehingga yang layak untuk didisain perluasan sawah menurut kesesuaian lahan seluas $1.354,27$ ha, dan tidak layak seluas 615,33 ha karena gambut dalam. Factor pembatas utama CL yang layak adalah salinitas tinggi dan genangan .

(3) Calon lahan perluasan sawah tahun 2017 di Kabupaten Kepulauan Meranti (623,29 ha) memiliki kelas kesesuaian lahan S2-S3 (615,37 ha) dan N1-N2 (7,92 ha), sehingga yang layak untuk didisain 
perluasan sawah seluas 615,37 ha dan tidak layak seluas 7,92 ha karena DHL tinggi. Faktor pembatas utama CL yang layak adalah salinitas tinggi dan lapisan sulfidik yang relative dangkal.

(4) Calon lahan perluasan sawah Provinsi Riau tahun 2017 hasil pengukuran seluas 2.693,05 ha, yang layak menurut kesesuaian lahan seluas 2.069,8 ha dan tidak layak seluas 623,25 ha.

\section{Potensi Pengairan}

Potensi pengairan merupakan salah satu faktor yang digunakan untuk menilai kelayakan calon lahan perluasan sawah. Beberapa variable yang digunakan untuk mendeskripsikan potensi pengairan yang sekaligus dipakai sebagai kriteria dalam penilaian kelayakan calon lahan dari aspek potensi pengairan adalah: keberadaan sumber air, kondisi daerah tangkapan air (DTA), kendala pemanfaatan sumber air, kecukupan air, dan sarana dan prasarana yang tersedia.

Menurut Warlina (2004), air irigasi yang baik adalah air yang dapat memenuhi segala fungsi air tanpa menimbulkan efek samping yang dapat mengganggu pertumbuhan tanaman dan merusak struktur serta kesuburan tanah. Selanjutnya menurut Keputusan Menteri Negara Lingkungan Hidup Nomor 115 Tahun 2003, kualitas air adalah kondisi kualitatif air yang diukur dan atau diuji berdasarkan parameter-parameter tertentu dan metode tertentu berdasarkan peraturan perundang-undangan yang berlaku.

Effendi (2003) mengatakan bahwa kualitas air dapat dinyatakan dengan parameter kualitas air. Parameter ini meliputi parameter fisik, kimia, dan mikrobiologis. Parameter fisik menyatakan kondisi fisik air atau keberadaan bahan yang dapat diamati secara visual/kasat mata. Yang termasuk dalam parameter fisik ini adalah kekeruhan, kandungan partikel/padatan, warna, rasa, bau, suhu, dan sebagainya. Parameter kimia menyatakan kandungan unsur/senyawa kimia dalam air, seperti kandungan oksigen, bahan organik (dinyatakan dengan BOD, COD, TOC), mineral atau logam, derajat keasaman, nutrient/hara, kesadahan, dan sebagainya. Parameter mikrobiologis menyatakan kandungan mikroorganisme dalam air, seperti bakteri, virus, dan mikroba pathogen lainnya. Berdasarkan hasil pengukuran atau pengujian, air sungai dapat dinyatakan dalam kondisi baik atau cemar. Syarat-syarat penggunaan irigasi: (1) Ada sumber air yang cukup, (2) Kualitas air memenuhi untuk pertanian, (3) Ada daerah yang berpotensi dijadikan sawah, (4) Tanah daerah tersebut cocok untuk tanaman, (5) Ada petani penggarap, dan (6) Bebas banjir.

Berdasarkan dari hasil kegiatan Survei potensi pengairan dapat dinyatakan bahwa:

(1) Hasil survei untuk calon lokasi di Desa Empat Balai dan Desa Sipungguk Kabupaten Kampar, potensi sumber air berasal dari saluran irigasi sekunder dan tersier yang sudah ada dengan sarana dan prasarana yang berfungsi dengan baik.

(2) Hasil survei untuk calon lokasi di Kabupaten Indragiri Hulu, Rokan Hilir dan Kepulauan Meranti, potensi sumber air berasal dari anak sungai atau parit/kanal baik yang alami maupun buatan.

(3) Desa Sendanu Darul Ihsan yang berada di Kecamatan Tebing Tinggi Timur Kabupaten Kepulauan Meranti berdasarkan survei lapangan tidak terdapat sumber air baik berupa sungai/anak sungai maupun kanal sesuai dengan kriteria yang ada. Sehingga lokasi tersebut tidak layak sebagai calon persawahan.

(4) Berdasarkan kelayakan potensi pengairan sebagai calon persawahan untuk Kabupaten Kampar seluas 77,17 Ha, dan Kabupaten Indragiri Hulu seluas 28,75 Ha, Kabupaten Rokan Hilir Seluas 1969,60 Ha dan Kabupaten Kepulauan Meranti seluas 584,12 Ha.

(5) Total luas yang layak berdasarkan potensi pengairan di empat kabupaten Provinsi Riau Tahun 2017 adalah seluas 2659,64 Ha.

(6) Berdasarkan hasil survei kualitas air di Kabupaten Rokan Hilir dan Kepulauan Meranti sebagian besar berada tidak jauh dengan laut, sehingga untuk sebagian lokasi ada yang terintrusi air laut. Hal ini disebabkan belum tersedianya tanggul, pintu klep dan saluran pembuangan. Tetapi secara umum untuk lokasi tersebut masih dapat dikatakan layak dan memenuhi kriteria sebagai calon lahan persawahan, apabila direncanakan dan dikelola dengan baik sistem jaringan irigasi termasuk sarana dan prasarananya.

\section{Sosial Ekonomi}

Aspek sosial ekonomi pengusahaan tanaman padi perlu dievaluasi. Hal itu penting, karena bila usahatani padi pada calon lahan yang akan dikembangkan tidak menguntungkan, maka petani akan malas mengusahakan tanah sawah yang akan dicetak. Menurut Hernanto (1996), faktor-faktor yang mempengaruhi keberhasilan usahatani adalah faktor internal dan faktor eksternal. Faktor-faktor pada usahatani itu sendiri (internal) yang berpengaruh terhadap berhasilnya usahatani antara lain adalah petani pengelola, tanah usahatani, tenaga kerja, modal, tingkat teknologi, kemampuan petani mengalokasikan penerimaan keluarga 
dan jumlah keluarga. Faktor-faktor di luar usaha tani (eksternal) yang dapat berpengaruh terhadap berhasilnya suatu usahatani antara lain: tersedianya sarana transportasi dan komunikasi, aspek-aspek yang menyangkut pemasaran hasil dan bahan usahatani (harga hasil, harga saprodi dan lain-lain), dan sarana penyuluh bagi petani.

Menurut Suratiyah (2006), faktor-faktor yang mempengaruhi besarnya biaya dan pendapatan adalah: (1) Faktor internal dan eksternal, terdiri dari: umur, pendidikan, pengetahuan, pengalaman, dan keterampilan, jumlah tenaga kerja keluarga, luas lahan dan modal. Sedangkan faktor eksternal terdiri dari keseterdiaan dan harga, dan (2) Faktor manajemen, yang mencakup aktivitas mengantisipasi faktor eksternal yang selalu berubah-ubah dan tidak sepenuhnya dikuasai. Petani sebagai manajer harus dapat mengambil keputusan dengan berbagai pertimbangan ekonomis sehingga diperoleh hasil yang memberikan pendapatan optimal.

Senada dengan pemikiran di atas, Rogers dan Shoemaker (1986) menyatakan faktor internal petani berpengaruh dalam penyebaran suatu ide baru. Adapun faktor internal petani adalah: umur, pendidikan formal, pengalaman berusahatani, dan motivasi. Sementara itu factor eksternal adalah keadaan/peristiwa yang mempengaruhi petani yang berasal dari luar diri, seperti: lahan, interaksi dengan penyuluh, sarana produksi, keterlibatan dalam kelompoktani dan akses kredit.

Mengacu pada Pedoman Teknis Survei dan Investigasi Calon Petani-Calon Lokasi dan Pemetaan Disain Perluasan Sawah Baru, yang diterbitkan oleh Direktorat Perluasan dan Perlindungan Lahan Direktorat Jenderal Prasarana dan Sarana Pertanian Kementerian Pertanian dari aspek calon petani adalah terdapat petani dan berdomisili di desa calon lokasi atau berdekatan dengan calon lokasi serta berkomitmen untuk bersawah. Jika terdapat lahan pada calon lokasi yang pemiliknya tidak berdomisili di desa calon lokasi, maka mengikuti hal-hal sebagai berikut: (a) Bersedia mengikuti program Perluasan Sawah Baru dan menunjuk penggarap untuk mengerjakan sawah yang akan dicetak, maka harus dinyatakan secara tertulis dalam surat kesepakatan antara pemilik lahan dengan penggarap; dan (b) Jika pemilik tidak bisa dihubungi/tidak bersedia mengikuti program dan lahan tersebut tidak bisa dimasukkan dalam program.

Survei dan Investigasi Sosial ekonomi dimaksudkan untuk mendapatkan data dan informasi yang berkaitan dengan kondisi sosial dan ekonomi masyarakat pada calon lokasi kegiatan perluasan sawah. Responden pada kegiatan ini meliputi masyarakat Calon petani dan bukan Calon petani kegiatan. Survei dan investigasi ini menjajaki beberapa kondisi berikut: (a) Identitas Calon petani kegiatan perluasan sawah; (b) Kesiapan calon petani dalam mengusahakan sawah baru dan kesediaannya untuk tidak mengalihfungsikan lahan sawah baru; (c) Kondisi sosial dan ekonomi yang berpotensi menjadi kendala kesuksesan program perluasan sawah; (d) Respon masyarakat sekitar non penerima terhadap rencana kegiatan perluasan sawah; (e) Analisa ekonomi terhadap rencana perluasan sawah; dan (f) Rekomendasi aspek sosial ekonomi terkait kondisi calon petani dan calon lokasi untuk kesuksesan program. Berdasarkan hasil survei dan investigasi social ekonomi dapat dinyatakan bahwa:

(1) Dari hasil identifikasi identitas responden dapat disimpulkan: (a) Sebagian besar calon petani perluasan sawah baru berjenis kelamin laki-laki kecuali di Kabupaten Kampar didominasi oleh perempuan karena budaya masyarakat di Kabupaten Kampar pengusahaan tanaman pangan di lakukan oleh perempuan; (2) Sebagian besar calon petani berada pada usia produktif, namun masih ditemukan petani yang berusia tidak produktif; (3) Sebagian besar calon petani perluasan sawah baru berpendidikan SMP/MTS atau lebih rendah, dan (4) rata-rata jumlah anggota keluarga pada lokasi SI-CPCL berkisar antara 2-6 orang.

(2) Secara keseluruhan calon petani menyatakan siap mengusahakan sawah baru dan kesediaannya untuk tidak mengalihfungsikan lahan sawah baru. Kesediaan untuk tidak mengalihfungsikan lahan sawah baru dinyatakan secara tertulis dalam bentuk surat pernyataan.

(3) Salah satu kondisi sosial dan ekonomi yang berpotensi menjadi kendala kesuksesan program perluasan sawah adalah adanya calon petani perluasan sawah baru yang bekerja sebagai karyawan/PNS. Namun demikian, berdasarkan hasil pengisian kuesioner mereka memiliki komitmen yang kuat untuk mengusahakan sawah baru yang akan dicetak.

(4) Walapun dalam jumlah yang sangat kecil, masih ditemukan calon petani yang tidak mengisi surat pernyataan antara pemilik dan penggarap. Disamping itu ditemukan petani yang berdomisili dari luas desa tempat sawah baru akan dicetak dan jaraknya dari tempat tinggal yang bersangkutan ke calon lokasi lebih dari $10 \mathrm{~km}$.

(5) Secara keseluruhan masyarakat bukan calon petani perluasan sawah baru menyatakan bahwa perluasan sawah baru akan memberikan dampak positif terhadap calon petani maupun kepada masyarakat sekitarnya. Melalui perluasan sawah baru akan meningkatkan ketersediaan beras untuk memenuhi 
kebutuhan masyarakat di lokasi perluasan sawah baru dan dapat meningkatkan perekonomian masyarakat baik yang terlibat langsung maupun tidak langsung dalam usahatani padi sawah.

\section{Pemetaan Disain}

Berdasarkan Hasil survei pemetaan situasi dan investigasi kawasan, survei evaluasi kesesuaian lahan, survei potensi pengairan serta survei dan investigasi sosial ekonomi, maka diperoleh luas calon lokasi yang layak untuk perluasan sawah Provinsi Riau Tahun 2017 adalah seluas 1,839.77 ha dari 2.891 ha total luas lahan yang diusulkan.

Perencanaan Disain cetak sawah dengan mempertimbangkan topografi, sumber air yang tersedia, bentuk areal calon lahan, kondisi jaringan saluran yang sudah ada, pengaruh dari luar seperti pasang air laut, vegetasi yang ada dan dana yang tersedia. Dengan pertimbangan-pertimbangan tersebut di atas maka dibuat rencana Disain Cetak Sawah pada masing-masing lokasi. Dari hasil survey dan analisa serta usulan dari dinas pertanian maka setelah melalui proses yang panjang ditetapkan hasil akhir yaitu untuk Kabupaten Kampar 3 paket hamparan dengan luas total $65 \mathrm{Ha}$, untuk Kabupaten Indragiri Hulu 3 paket hamparan dengan luas total $22 \mathrm{Ha}$, untuk Kabupaten Rokan Hilir 3 paket hamparan dengan luas total 1.241 Ha, dan Kabupaten Kepulauan Meranti 12 paket hamparan dengan luas total 492 Ha. Dengan luas total untuk Provinsi Riau di rencanakan Detail Disain seluas 1.820 Ha. Rekap hasil akhir pengukuran dan disain pemetaan perluasan sawah di Provinsi Riau Tahun 2017 disajikan pada Tabel 1.

Tabel 1. Rekap hasil akhir pengukuran dan disain pemetaan perluasan sawah di provinsi riau tahun 2017

\begin{tabular}{|c|c|c|c|}
\hline No & Kabupaten/Desa & Hasil Pengukuran $(\mathrm{Ha})$ & $\begin{array}{c}\text { Disain } \\
\text { Sawah }(\mathrm{Ha})\end{array}$ \\
\hline A. & Kabupaten Kampar & 65.96 & 65.00 \\
\hline 1. & Pangkalan Serik & 32.15 & 32 \\
\hline 2. & Empat Balai & 5.14 & 5 \\
\hline 3. & Sipungguk & 28.67 & 28 \\
\hline B. & Kabupaten Indragiri Hulu & 22.99 & 22.00 \\
\hline 1. & Kota Medan & 5.35 & 5 \\
\hline 2. & Koto Tuo & 7.57 & 7 \\
\hline 3 . & Selunak & 10.07 & 10 \\
\hline C. & Kabupaten Rokan Hilir & $1,252.83$ & $1,241.00$ \\
\hline 1. & Parit Aman & 320.71 & 320 \\
\hline 2. & Suak Air Hitam & 530.26 & 530 \\
\hline 3. & Teluk Piyai & 401.86 & 391 \\
\hline D. & Kabupaten Kepulauan Meranti & 497.99 & 492.00 \\
\hline 1. & Bina Sempian & 83.25 & 83 \\
\hline 2. & Kedabu Rapat & 24.44 & 24 \\
\hline 3. & Mekar Baru & 30.83 & 30 \\
\hline 4. & Maini Darul Aman & 86.99 & 86 \\
\hline 5. & Tanjung Sari & 48.17 & 48 \\
\hline 6. & Teluk Buntal & 22.64 & 22 \\
\hline 7. & Sungai Tohor Barat & 16.75 & 16 \\
\hline 8. & Pelantai & 24.30 & 24 \\
\hline 9. & Meranti Bunting & 10.55 & 10 \\
\hline 10. & Kuala Merbau & 43.38 & 43 \\
\hline 11. & Semukut & 62.68 & 62 \\
\hline 12. & Mengkirau & 44.01 & 44 \\
\hline & Total & $1,839.77$ & $1,820.00$ \\
\hline
\end{tabular}

Anggaran biaya yang disediakan untuk pekerjaan cetak sawah ini telah ditentukan pagunya maksimum adalah 16 juta/Ha oleh pemerintah pusat. Pagu sebesar 16 juta/Ha adalah harga maksimum yang diperbolehkan, apabila lahan tidak berat dan prasarana yang dibangun tidak banyak maka dana tersebut bisa kurang dari 16 juta/Ha. Tetapi apabila medannya berat, lokasinya sulit dan perlu banyak prasarana yang dibangun apabila dana kurang maka maksimum adalah 16 juta/Ha dengan konsekwensi dikurangi pembangunan prasarana yang kurang penting seperti pematang sawah atau membuat bangunan sederhana yang nantinya diusulkan pada pemda untuk dibuatkan yang permanen yang lebih bagus. 
Rencana anggaran biaya yang direncanakan dari hasil Detail Disain (DD) Cetak sawah seluas 1.820 Ha adalah sebesar Rp. 29.120.000.000,- (Dua Puluh Sembilan Milyar Seratus Dua Puluh Juta Rupiah). Tabel rencana anggaran biaya hasil detail disain di Provinsi Riau disajikan pada Tabel 2.

Tabel 2. Rencana anggaran biaya hasil disain pemetaan perluasan sawah provinsi riau seluas 1.820 ha

\begin{tabular}{|c|c|c|c|c|c|c|}
\hline \multirow{2}{*}{ No. } & \multicolumn{3}{|c|}{ Lokasi } & \multirow{2}{*}{$\begin{array}{c}\text { Disain } \\
\text { Sawah }(\mathrm{Ha})\end{array}$} & \multirow{2}{*}{$\begin{array}{l}\text { Harga Satuan } \\
\text { (Rp.) }\end{array}$} & \multirow{2}{*}{$\begin{array}{c}\text { Jumlah Harga } \\
\text { (Rp.) }\end{array}$} \\
\hline & Kabupaten & Kecamatan & Desa & & & \\
\hline 1 & \multirow{3}{*}{ Kampar } & Siak Hulu & Pangkalan Serik & 32 & 16.000 .000 & 512.000 .000 \\
\hline 2 & & Kuok & Empat Balai & 5 & 16.000 .000 & 80.000 .000 \\
\hline 3 & & Salo & Sipungguk & 28 & 16.000 .000 & 448.000 .000 \\
\hline 4 & \multirow{4}{*}{$\begin{array}{l}\text { Indragiri } \\
\text { Hulu }\end{array}$} & Kelayang & Koto Medan & 5 & 16.000 .000 & 80.000 .000 \\
\hline 5 & & \multirow{2}{*}{ Batang Peranap } & Koto Tuo & 7 & 16.000 .000 & 112.000 .000 \\
\hline 6 & & & Selunak & 10 & 16.000 .000 & 160.000 .000 \\
\hline 7 & & Pekaitan & Parit Aman & 320 & 16.000 .000 & 5.120 .000 .000 \\
\hline 8 & \multirow[t]{2}{*}{ Rokan Hiir } & Bangko & Suak Air Hitam & 530 & 16.000 .000 & 8.480 .000 .000 \\
\hline 9 & & Kubu & Teluk Piyai & 391 & 16.000 .000 & 6.256 .000 .000 \\
\hline 10 & \multirow{12}{*}{$\begin{array}{l}\text { Kepulauan } \\
\text { Meranti }\end{array}$} & \multirow{2}{*}{ Rangsang Pesisir } & Bina Sempian & 83 & 16.000 .000 & 1.328 .000 .000 \\
\hline 11 & & & Kedabu Rapat & 24 & 16.000 .000 & 384.000 .000 \\
\hline 12 & & Rangsang Barat & Mekar Baru & 30 & 16.000 .000 & 480.000 .000 \\
\hline 13 & & \multirow{2}{*}{ Tebing Tinggi Barat } & Maini Darul Aman & 86 & 16.000 .000 & 1.376 .000 .000 \\
\hline 14 & & & Tanjung Sari & 48 & 16.000 .000 & 768.000 .000 \\
\hline 15 & & \multirow{2}{*}{$\begin{array}{l}\text { Tebing Tinggi } \\
\text { Timur }\end{array}$} & Teluk Buntal & 22 & 16.000 .000 & 352.000 .000 \\
\hline 16 & & & $\begin{array}{l}\text { Sungai Tohor } \\
\text { Barat }\end{array}$ & 16 & 16.000 .000 & 256.000 .000 \\
\hline 17 & & \multirow{2}{*}{ Merbau } & Pelantai & 24 & 16.000 .000 & 384.000 .000 \\
\hline 18 & & & Meranti Bunting & 10 & 16.000 .000 & 160.000 .000 \\
\hline 19 & & \multirow{2}{*}{ Pulau Merbau } & Kuala Merbau & 43 & 16.000 .000 & 688.000 .000 \\
\hline 20 & & & Semukut & 62 & 16.000 .000 & 992.000 .000 \\
\hline \multirow[t]{2}{*}{21} & & Tasik Putri Puyu & Mengkirau & 44 & 16.000 .000 & 704.000 .000 \\
\hline & & Total Keseluruhan & & 1.820 & & 29.120 .000 .000 \\
\hline
\end{tabular}

\section{KESIMPULAN}

Berdasarkan Hasil survei pemetaan situasi dan investigasi kawasan, survei evaluasi kesesuaian lahan, survei potensi pengairan serta survei dan investigasi sosial ekonomi, maka diperoleh luas calon lokasi yang layak untuk perluasan sawah Provinsi Riau Tahun 2017 adalah seluas 1,839.77 ha dari 2.891 ha total luas lahan yang diusulkan. Sebagian besar lahan yang tidak layak karena teridentifikasi sebagai lahan yang masuk pada kawasan hutan.

Berdasarkan hasil survei lapangan dan evaluasi kelayakan menurut kesesuaian lahan dapat disimpulkan dan direkomendasikan bahwa: (1) terdapat calon lahan yang memiliki kadar besi tinggi dan salinitas tinggi, oleh karenanya perlu pencucian besi dan garam-garam melalui pengelolaan air irigasi dan drainase, (2) terdapat calon lahan dengan faktor pembatas genangan seperti di Desa Parit Aman sehingga perlu dibuat saluran drainase yang cukup lebar untuk membuang kelebihan air yang selalu tergenang, (3) terdapat calon lahan dengan pembatas lapisan sulfidik (pirit), disarankan pada waktu pembukaan lahan jangan sampai terungkap dan perlu menjaga tinggi muka air agar lapisan sulfidik tidak teroksidasi.

Berdasarkan hasil survei potensi pengairan perluasan sawah Provinsi Riau Tahun 2017, kondisi di lapangan secara umum diperlukan tata kelola sistem jaringan irigasi dengan baik, dimana direncanakan saluran pemberi untuk mengatur pemberian air dan saluran pembuang untuk membuang kelebihan air hujan agar tidak mengganggu pertumbuhan tanaman di sawah. Pengaruh masuknya air laut ke dalam lahan akan dikontrol dengan tanggul keliling dan bangunan pintu air untuk menghambat masuk ke dalam lahan. Sistem saluran disini dapat berfungsi saluran pemberi dan sekaligus untuk menahan air hujan dan menyimpan air hujan tetapi bila berkelebihan dapat berfungsi sebagai saluran drainase yang membuang air ke saluran alam atau ke laut.

Berdasarkan hasil survei dan investigasi sosial ekonomi dapat disimpulkan dan direkomedasikan bahwa: (1) terdapat calon petani yang belum berpengalaman berusahatani padi, sehingga untuk mensukseskan Program Perluasan Sawah Baru, maka diperlukan pendampingan dan penyuluhan kepada petani dari aspek teknis produksi dan manjemen usahatani serta manajemen pengelolaan kelompok tani, (2) terdapat calon petani yang berusia tidak produktif, maka pendampingan dan penyuluhan hendaknya melibatkan anggota 
keluarga petani yang membantu kegiatan usahatani padi sawah yang dilakukan, dan (3) terhadap calon petani yang tidak menandatangi surat pernyataan antara pemilik dan penggarap serta berdomisili lebih dari $10 \mathrm{~km}$ dari calon lokasi untuk tidak dilibatkan sebagai peserta Program Perluasan Sawah Baru.

Dalam perluasan sawah baru biaya yang ada sudah dipatok sebesar Rp 16 juta/ha, sedangkan di lapangan banyak kesulitan yang ditemukan, tergantung topografi, lokasi dan kebutuhan prasarana yang dibangun. Oleh karenanya ada lokasi yang membutuhkan anggaran lebih karena harus membangun sejumlah prasarana seperti pintu permanen atau tanggul agar lahan persawahan aman terhadap bahaya banjir atau pasang. Oleh karenanya diperlukan kerjasama dengan pemerintah daerah khususnya Dinas Pekerjaan Umum dan Penataan Ruang untuk melengkapi dan membangun sejumlah prasarana irigasi seperti bangunan pintu air agar lahan sawah yang telah dicetak dapat dioptimalkan pemanfaatannya. Disamping itu, perhitungan biaya pembukaan lahan berdasarkan kondisi tutupan vegetasi/tutupan lahan. Disarankan agar dasar perhitungan pembukaan lahan juga menggunakan dasar perhitungan penggunaan alat berat.

\section{DAFTAR PUSTAKA}

BBSDLP. 2011. Petunjuk Teknis Evaluasi Lahan Untuk Komoditas Pertanian. Balai Besar Penelitian dan Pengembangan Sumberdaya Lahan Pertanian Badan Penelitian dan Pengembangan Pertanian Kementerian Pertanian, Bogor.

Direktorat Perluasan dan Perlindungan Lahan Direktorat Jenderal Prasarana dan Sarana Pertanian Kementerian Pertanian. 2016. Pedoman Teknis Survei dan Investigasi Calon Petani-Calon Lokasi dan Pemetaan Desain Perluasan Sawah Tahun 2016. Direktorat Perluasan dan Perlindungan Lahan Direktorat Jenderal Prasarana dan Sarana Pertanian Kementerian Pertanian, Jakarta.

Effendi, H. 2003. Telaah Kualitas Air Bagi Pengelolaan Sumber Daya dan Lingkungan Perairan. Yogyakarta: Kanisius.

Fagi, A.M, dan I. Las. 1988. Lingkungan Tumbuh Padi. Bogor: Balai Penelitian Tanaman Pangan Sukamandi. Balai Penelitian Tanaman Pangan Kementerian Pertanian Republik Indonesia.

Hernanto, F. 1996. Ilmu Usahatani. Jakarta: Penebar Swadaya.

Rogers, E.M. and F. Shoemaker. 1986. Communication of Inovation: A Coors Cultural Approach. New York: The Free Press.

Suratiyah, K. 2015. Ilmu Usahatani. Jakarta: Penebar Swadaya.

Undang-Undang Republik Indonesia Nomor 18 Tahun 2012 Tentang Pangan (Tambahan Lembaran Negara Republik Indonesia Nomor 5360).

Utama, Z.H. 2015. Budidaya Padi Pada Lahan Marjinal. Yogyakarta: Andi Offset.

Warlina, L. 2004. Pencemaran Air: Sumber, Dampak, dan Penanggulangannya. Disertasi. Program Pasca Sarjana, Institut Pertanian Bogor, Bogor. 